\title{
FERREIRA, Luis. Los tambores del candombe. Montevideo: Colihue-Sepé Ediciones S.R.L, 1997. 213 p.
}

\section{Reginaldo Gil Braga* \\ Universidade Federal do Rio Grande do Sul - Brasil}

Do Uruguai, nosso vizinho de fronteiras, pouco sabemos além da sua vocação pastoril e do futebol. Menos ainda sabemos sobre sua população de afro-descendentes. Os dados trazidos por Mundo Afro (cuja fundação recente em 1989 vem contribuindo para a defesa e implementação dos direitos das populações afro-uruguaias) e pelo Programa das Nações Unidas para o Desenvolvimento (PNUD) nos dão conta de que 5,76\% da população total uruguaia é de negros e que $90 \%$ deles vivem no limite da pobreza, trabalhando no setor de serviços e praticamente sem acesso ao ensino universitário. Dentro do país a visibilidade da população negra está relegada ao futebol ou ao carnaval, onde lhes é oferecido espaço de promoção.

Luis Ferreira ao lançar esse livro traz elementos fundamentais para compreender o Candombe uruguaio, manifestação do carnaval negro do país, para além dos "Desfile de las llamadas" e das apresentações disciplinadas das "Sociedades de Negros y Lubolos" no "Concurso Oficial de Agrupaciones Carnavalescas" do "teatro de verano".

Através de uma organização tripartida o autor aborda diacrônica e sincronicamente o universo sócio-cultural das comparsas e da população negra de Montevidéu ( $l^{\text {a }}$ parte); faz a descrição e transcrição musical dos "toques" ( $2^{\mathrm{a}}$ parte) e a análise musical (texto musical) e das representações culturais mediadas pela música ( $3^{\mathrm{a}}$ parte).

Na primeira parte do livro o autor repassa as principais fontes bibliográficas sobre a entrada de populações negras e os meandros que propiciaram o desenvolvimento dentro da sociedade uruguaia, de características europeizantes, de negros em confrarias católicas e em "naciones", durante o período colonial e posteriormente em "juntas de morenos", em clubes que realizavam os "bailes de la raza" e em sociedades de ajuda mútua e carnavalescas, mais tarde consagradas como "Sociedades de Negros y Lubolos".

* Doutorando em Etnomusicologia.

Horizontes Antropológicos, Porto Alegre, ano 5, n. 11, p. 210-212, out. 1999 http://dx.doi.org/10.1590/S0104-71831999000200011 
Além do aspecto competitivo o autor nos mostra a dimensão lúdica intra-muros da sociabilidade afro-uruguaia e a irradiação e fusão do Candombe (numa exposição rápida, que poderia ser explorada em estudos futuros) no campo das orquestras de tango, da música afro-caribenha, do pop latino, do jazz, dos cancionistas populares, no repertório das "murgas" (grupos satíricos de carnaval) e da música erudita.

O seu objetivo de produzir um material antes de tudo didático sobre a música dos tambores e destinado principalmente a docentes e agentes culturais da comunidade afro-uruguaia segue na descrição da estrutura das comparsas, do ciclo de "sallidas" ao longo do ano, festas familiares, tradições de bairros, de troncos familiares ligados ao tambor e toma corpo principalmente a partir da descrição dos toques dos tambores.

$\mathrm{Na}$ segunda parte do livro, Luis Ferreira, buscando atingir um público maior, trabalha com os dois sistemas de transcrição musical apontados por Charles Seeger: a descritiva (esquemática e voltada para uma finalidade didática, por isso a utilização de um sistema de representação numérico-silábico onde "toques", posição das mãos são representados como uma alternativa para não iniciados na leitura musical) e a prescritiva, baseada na escrita tradicional da música ocidental. É empregada a noção de time-line desenvolvida por Kwabena Nketia, tão de acordo aos sistemas musicais de derivação africana que apresentam uma circularidade rítmica baseada em vibrações rápidas; além disso são abordadas as performances específicas nos diferentes cenários do Candombe: "llamadas", "tablados" e clubes de bairro.

São introduzidos os sinais da escrita descritiva, os toques básicos, a combinação polirítmica do conjunto de tambores, os papéis e funções de cada tambor no conjunto, as regras subjacentes à improvisação e formação de variantes e os aspectos que formam a identidade sonora dos diferentes bairros através da análise dos diferentes toques de "piano", o tambor maior empunhado pelos continuadores das linhagens familiares. As transcrições musicais são baseadas em uma riqueza de informações que só mesmo uma participação ativa como "tamborero" de comparsas, músico de estúdio e docente em oficinas poderiam proporcionar.

A terceira e última parte do seu livro pretende ter um caráter interpretativo baseado em três modelos de análise da música dos tambores: 1) estrutura dos toques básicos segundo suas diferentes acentuações e relacionamentos com a pulsação subjacente básica; 2) sistema de "pergunta" e "resposta" e 3) um olhar antropológico sobre as representações sócio-culturais a partir do material musical. 
A questão das pulsações é bem resolvida pela exposição em transcrição musical da trama de pulsações próprias reiteradas por cada tambor ("piano", "repique" e "chico") e pela presença subjacente do pulso básico no movimento dos passos e dos braços dos tamboreiros em movimento. O sistema de "chamada" e "resposta" é interpretado por Luis Ferreira a partir das observações do musicólogo cubano Argeliers León sobre "franjas" e "planos tímbricos", que é alargado pelo autor para "franjas de ação", onde cada grupo de tambores possui formas de interação e comportamentos próprios dados pela trama polirítmica dos "pianos" e "chicos" e pelos elementos formantes da improvisação executada pelos "repiques". Para a análise da estrutura simbólica dos tambores outras leituras, agora desde a performance, são exploradas: a comunicação visual e a expressão motora dos participantes como reveladoras de ancestralidade (através de uma espécie de transe durante as performances, não reconhecido pelos tamboreiros) e a presença de uma religiosidade esvaziada de significados religiosos e substituída por uma religiosidade aparente.

Seguindo os modelos da Etnomusicologia, o autor tratou de construir sua análise de abordagem da cultura através da música, como por exemplo, Kwabena Nketia propõe. As interpretações dos aspectos rítmicos e do sistema de "pergunta" e "resposta" na percussão levantam a possibilidade da identidade a partir do musical, assim como a comunicação visual e a corporalidade dos tamboreiros indicariam sentimentos de religiosidade e ancestralidade mediados pelo transe não-reconhecido. Porém, nos parece que um referencial teórico construído a partir da Antropologia e/ou Sociologia seria mais eficiente do que o fornecido pela Psicologia para aprofundar essas questões - fazendo a "costura" entre a teoria musical avançada pela sua abordagem Etnomusicológica e as representações sócio-culturais.

O livro é rico em material ilustrativo (fotos de contextos carnavalescos, desenhos didáticos, mapas e esquemas) e em diagramas e partituras musicais. A organização das fontes utilizadas aparece segundo: fontes documentais, orais, bibliográfica (indexada por assuntos) e de vídeos. Ao final do livro é oferecida uma seleção discográfica ao leitor.

Finalmente, o trabalho de Luis Ferreira é um marco na literatura sobre os estudos de música e sociedade no contexto do Candombe uruguaio, pois, ante a ausência de bibliografia atualizada sobre o tema e pelo pioneirismo de buscar uma dimensão didática de formação de docentes, constitui-se num sopro de vida e paixão ao universo dos tambores afro-uruguaios. 